Institute of $\mathbf{F}_{\text {ood and }} \mathbf{A}_{\text {gricultural }} \mathbf{S}_{\text {ciences }}$

\title{
2003 Handbook of Employment Regulations Affecting Florida Farm Employers and Workers: Income Tax Withholding for Farm Workers [Federal] ${ }^{1}$
}

Leo C. Polopolus, Michael T. Olexa, Fritz Roka, and Carol Fountain ${ }^{2}$

\section{Purpose}

To withhold federal income taxes on the cash wages of farmworkers.

\section{Who Must Comply}

Farm employers are required to withhold federal income taxes from any employee's wages (including family members) if either of the following two tests is met:

- A worker is paid $\$ 150$ or more per year.

- The farm employer's total annual labor expenditures for the year are $\$ 2,500$ or more.

\section{Exemptions}

Farm employers are exempt from withholding income taxes from workers paid less than $\$ 150$ in a calendar year or if the farm employer's annual payroll was less than $\$ 2,500$.

Hand harvest employees are exempt from income tax withholding if they meet all these criteria:

- Are paid by the piece on a job that is ordinarily paid on a piece rate basis.

- Commute daily to the farm from a permanent residence.

1. This is EDIS document FE403, a publication of the Department of Food and Resource Economics, Florida Cooperative Extension Service, Institute of Food and Agricultural Sciences, University of Florida, Gainesville, FL. Published July 2003. This information is included in Circular 1200, Handbook of Employment Regulations Affecting Florida Farm Employers and Workers. First published February 1992 as Circular 1043 . Revised December 2002 as Circular 1200. Please visit the EDIS website at http://edis.ifas.ufl.edu.

2. Leo C. Polopolus, Professor Emeritus, Department of Food and Resource Economics, University of Florida, Gainesville, FL; Michael T. Olexa, Professor, Department of Food and Resource Economics, University of Florida, Gainesville, FL; Fritz Roka, Associate Professor, Department of Food and Resource Economics, Southwest Florida Research and Education Center, Immokalee, FL; and Carol Fountain, Assistant Editor, Department of Food and Resource Economics, University of Florida, Gainesville, FL; Florida Cooperative Extension Service, Institute of Food and Agricultural Sciences, University of Florida, Gainesville, FL.

This document is designed to provide accurate, current, and authoritative information on the subject. However, since the laws, administrative rulings, and court decisions on which it is based are subject to constant revision, portions of this publication could become outdated at any time. This publication is distributed with the understanding that the authors are not engaged in rendering legal or other professional advice, and the information contained herein should not be regarded as a substitute for professional advice. For these reasons, the utilization of these materials by any person constitutes an agreement to hold harmless the authors, the Institute of Food and Agricultural Sciences, and the University of Florida for any liability claims, damages, or expenses that may be incurred by any person as a result of reference to or reliance on the information contained in this publication.

The Institute of Food and Agricultural Sciences is an equal opportunity/affirmative action employer authorized to provide research, educational information and other services only to individuals and institutions that function without regard to race, color, sex, age, handicap, or national origin. For information on obtaining other extension publications, contact your county Cooperative Extension Service office. Florida Cooperative Extension Service/Institute of Food and Agricultural Sciences/University of Florida/Christine Taylor Waddill, Dean. 
- Were employed in agriculture fewer than thirteen weeks during preceding calendar year.

Wages paid to exempt employees do count, however, toward the employer's total annual labor expenditures of $\$ 2,500$ or more.

Taxable wages includes salaries, commissions, bonuses, wages, fees, or any items of value. If a worker is paid fully or partially with commodities, the value of the commodities is treated as income subject to withholding and Social Security. However, the value of meals and lodging furnished for the convenience of the employees is not taxable under most circumstances.

Employers of permanent residents and/or workers holding I-688 and I-688A cards issued under the Immigration Reform and Control Act of 1986 should consider these workers subject to income tax withholding.

In contrast, $\mathrm{H}-2 \mathrm{~A}$ workers who are nonresident aliens admitted legally to perform agricultural service on a temporary basis are not required to have federal income taxes withheld.

\section{Employer Responsibilities}

Employers are required to:

- Ensure that workers complete Form W-4, "Employee's Withholding Allowance Certificate," at the time of employment. If the worker chooses to claim full exemption from withholding on Line 7 of the W-4, the employer may accept the claim of exempt status.

- Withhold income taxes on cash wages paid for agricultural labor. Copies of Form W-4 must be sent to the IRS when an employee either claims more than ten exemptions or claims exemption from withholding and wages exceeding $\$ 200$ per week.

- Send payments to the IRS through a local bank. The payments must be accompanied by Form 8109 , the federal tax deposit coupon. The IRS automatically sends you a coupon book when you apply for an employer ID number. The amount of combined Social Security (FICA) and withheld income tax determines how often deposits must be made. The deposit schedule is identical to that for depositing FICA (Social Security) taxes.

- Give employees Form W-2, "Wages and Tax Statement," by January 31 st for preceding year.

- Send copy "A" of Form W-2 and Form W-3 ("Transmittal of Income and Tax Statements") together with Form 943 ("Employer's Annual Tax Return for Agricultural Employers") to the IRS by January 31 st. This can be deferred if the tax was paid in full by February 10th.

Farm employers may rely on a farm labor contractor (FLC) for withholding FICA and income taxes from worker wages. However, if an FLC fails to submit withheld wages according to the law, employers may, under the joint employer principle, be held liable for unpaid withholding and penalties.

Employers need to be aware that the Department of Labor's (DOL) Wage and Hour Division may enforce failure to deposit withheld FICA and income taxes in a timely manner as failure to pay wages when due, a violation of the Fair Labor Standards Act.

This would add DOL fines and penalties to the fines and penalties levied by the IRS for failure to withhold and deposit taxes in a timely manner.

\section{Determining Employer of Farmworkers}

Many farmers hire or contract with crew leaders or labor contractors to manage their farmworkers. Whether the farmer or the crew leader/labor contractor is the employer of the farmworker (and has responsibility for submitting wage reports) depends on the circumstances. (See EDIS document FE406, Migrant and Seasonal Agricultural Worker Protection Act (MSPA) [Federal], for the latest definition of joint employment.)

Independent labor contractors may handle all the wage-reporting responsibilities. However, if a written agreement states that the crew leader is the farmer's employee, the farmer obviously is responsible for all wage reporting and record keeping. 


\section{Written Agreement}

If the farmer and the crew leader agree that the farmer will handle Social Security and IRS tax withholding matters (and that the crew leader is the farmer's employee), they should prepare a written agreement. No special form is needed, but the agreement should be signed by both parties and include the following:

- Names and addresses of the farmer and the crew leader.

- Location of the farm, kind of crop and operation, and approximate dates of the work.

- Statement that the crew leader will furnish a crew to do the work.

- Satement that the crew leader and crew workers are employees of the farmer who will report their wages and pay Social Security and Medicare taxes that are due.

- Statement about charges made by the crew leader for services, wages to be paid to workers and any transportation, housing and insurance to be provided.

(See EDIS document FE415, Social Security and Medicare [Federal].)

\section{Employee Tax Obligations}

Farm employees should be aware that every citizen or resident of the United States, whether an adult or minor, who has $\$ 4,000$ or more income must file a return. In the case of married couples filing joint returns, the amount is $\$ 6,700$. These figures increase to $\$ 5,000$ if one individual is over sixty-five years of age and to $\$ 7,500$ if both are over sixty-five. The taxable income thresholds change from year to year; the current amount should be obtained from IRS.

A farm employee is required to file a declaration of estimated tax using Form 1040-ES if he or she expects to have a tax liability of $\$ 500$ or more from sources not subject to withholding. The tax may be paid in four equal installments.

\section{Related Information}

- Circular A, Agricultural Employer's Tax Guide, Publication No. 51, Internal Revenue Service. (Revised annually)

- Circular E, Employer's Tax Guide, Publication 15, Internal Revenue Service. (Revised annually)

- Revenue Reconciliation Act of 1989, Subtitle F, Part IV, Section 7631 (a), (b), and (c).

- Labor Bulletin No. 470, Florida Fruit and Vegetable Association, Orlando, FL, December $5,1989$.

- Social Security Handbook for Farmers. Social Security Administration. (Revised annually)

\section{Responsible Agency}

U.S. Department of the Treasury

Internal Revenue Service

Washington, D.C.

http://www.irs.gov

For local offices, see the telephone directory for

- United States Government

- Internal Revenue Service

For information, dial toll-free 1(800) 829-1040

To order tax forms, dial toll-free 1(800) 829-3676 